\title{
JOURNAL OF ADVANCED
}

\section{BOTANY AND ZOOLOGY}

Journal homepage: http://scienceq.org/Journals/JABZ.php

\section{Phytochemical Composition and Antimicrobial Properties of the Seeds of Khaya senegalensis (Desc.) A. Juss.}

\section{Idu ${ }^{1 *}$, J.O. Erhabor ${ }^{1}$, E.O. Oshomoh ${ }^{2}$, P.O. Ovuakporie-Uvo ${ }^{1}$}

1Department of Plant Biology and Biotechnology, University of Benin, PMB 1154, Benin City, Edo State, Nigeria.

2Department of Science Laboratory Technology, University of Benin, Benin City, Edo State, Nigeria.

*Corresponding author: M. Idu, Phone: 08050607009, E-mail: mcdonaldidu@gmail.com

Received: June 12, 2014; Accepted: July 17, 2014, Published: July 17, 2014.

\section{ABSTRACT}

The antimicrobial and phytochemical properties of the aqueous and ethanol extracts of the seed of Khaya senegalensis were determined. The test organisms, Bacillus subtilis, Pseudomonas aeruginosa, Escherichia coli, Staphylococcous aureus, Candida albicans, Penicillum notatum and Aspergillus niger were found to be sensitive to both extracts. However, the bacteria isolates were generally more sensitive than the fungal isolates. E. coli was the most sensitive isolate with a Minimum Inhibitory Concentrations (MIC) of $6.0 \mathrm{~mm}$. Standard phytochemical analysis was carried out to determine the qualitative and quantitative composition of the micro and macro elements. Phytochemical test revealed the presence of oxalate, phytate, saponin, alkaloid, flavonoid, tannin, sodium, potassium, calcium, magnesium, iron, zinc, lead, manganese and chromium. The study showed that aqueous and ethanol extracts of the seed of $K$. senegalensis can be used as antimicrobial agents and considered safe within the administered doses.

Keywords: Antimicrobial, Phytochemical, Extracts, Khaya senegalensis, Seed.

\section{INTRODUCTION}

The efficacy of many medicinal plants in the treatment of many diseases has been put to test in many laboratories [1]. Plants continue to play a prominent role in primary health care of about $80 \%$ of the world's population [2]. Several published reports have shown the effectiveness of traditional herbs against microorganisms. As a result, plants are one of the bedrocks of modern medicine.

Khaya senegalensis (Desc.) A. Juss. commonly known as African mahogany is a tree with shiny foliage up to $25 \mathrm{~m}$ or more with exfoliating barks, young branches with dark, grayish-brown lenticels and leaves of $15-60 \mathrm{~cm}$ or more. The fruit is normally 4-valved; 4-6 cm in diameter. K. senegalensis is an important multipurpose tree in its natural range within sub-Saharan Africa. It is particularly valued for timber, fuel wood and medicinal purposes as well as being a popular shade and amenity tree [3]. Both the seeds and leaves have also been used as medicine for treating fever and headache, whilst preparations made from the roots have been used against syphilis, leprosy and as an aphrodisiac [4]. Aside from its medicinal values, the bark is can be used for tanning of leather as it is quite high in tannins [5].The study is aimed at assessing the antimicrobial and phytochemical values of the plant part (seed).

\section{MATERIALS AND METHODS}

Sample collection, identification and treatment: The seeds of K.senegalensis were collected from Adamawa State, and identified by Professor MacDonald Iduof the Department of Plant Biology and Biotechnology, Faculty of Life Sciences, University of Benin. They were air dried under room temperature and ground into fine powder using the laboratory mortar and pestle in the Department of Pharmacognosy, Faculty of Pharmacy, University of Benin. The powdered samples were stored in clean, dry, and air-tight used mayonnaise bottles and kept in a cool, dry place until further treatment.

The extraction procedure: Two solvents were used for the preparation of the extracts-distilled water and ethanol (95\% concentration). The aqueous extract was prepared by weighing out $100 \mathrm{~g}$ of the powered plant/oil and dissolving in $100 \mathrm{ml}$ (100 $\mathrm{mg} / \mathrm{ml}$ ) of distilled water then stirring vigorously with a glass rod. The mixture was allowed to settle for 24 hours, using the infusion method. The extract was then filtered, using Whatman No. 1 filtered paper.

The ethanol extract was obtained by weighing out $100 \mathrm{~g}$ of the ground plant material into $100 \mathrm{ml}$ of ethanol and stirring vigorously with a glass rod. The combination was allowed to settle for 24 hours, using the infusion method. The extract was filtered also using Whatman No. 1 filter paper. The filtrate was evaporated in a water bath and the residue reserved as stock concentration.

Different concentrations of the extracts was prepared by diluting $0.05 \mathrm{~g}, 0.10 \mathrm{~g}, 0.15 \mathrm{~g}, 0.20 \mathrm{~g}, 0.30 \mathrm{~g}, 0.40 \mathrm{~g}$ and $0.50 \mathrm{~g}$ of the extracts in $10 \mathrm{ml}$ of distilled water to obtain concentrations 
of $5.0 \mathrm{mg} / \mathrm{ml}, 10.0 \mathrm{mg} / \mathrm{ml}, 15 \mathrm{mg} / \mathrm{ml}, 20 \mathrm{mg} / \mathrm{ml}, 30 \mathrm{mg} / \mathrm{ml}, 40$ $\mathrm{mg} / \mathrm{ml}, 50 \mathrm{mg} / \mathrm{ml}$.

Determination of antibacterial/ antifungal activity: Stock cultures of the micro-organisms were maintained at $4^{\circ} \mathrm{C}$ in Nutrient agar and potato dextrose agar. Inoculums used for the experiment were a broth of each microbial species grown for 24 hours and diluted in distilled water. Serial dilutions with distilled water were made aseptically using sterilized pipette tubes. Nutrient media was poured into sterile $90 \mathrm{~mm}$ petridishes and allowed to set for 30 minutes. The different organisms were flooded in the medium. Then a $4 \mathrm{~mm}$ cork borer was used to punch 3 equidistant holes in the middle of the inoculate agar medium. The extracts were tested at $5.0 \mathrm{mg} / \mathrm{ml}$, $10 \mathrm{mg} / \mathrm{ml}, 15 \mathrm{mg} / \mathrm{ml}, 20 \mathrm{mg} / \mathrm{ml}, 30 \mathrm{mg} / \mathrm{ml}$ and $40 \mathrm{mg} / \mathrm{ml}$ concentrations. The holes were filled with $0.2 \mathrm{ml}$ of the extract at the different concentrations and incubated at $37^{\circ} \mathrm{C}$ for 24 hours after which the zones of inhibition were measured using a transparent meter rule. The process was repeated in the case of fungi however, inoculated plates were stored at room temperature for 72 hours after which the zones of inhibition were measured using a transparent meter rule.

Determination of Minimum Inhibitory Concentrations (MICs): The extracts were incorporated into molten nutrient broth and Potato dextrose broth for bacteria and fungi respectively, at concentrations of $1.0 \mathrm{mg} / \mathrm{ml}$ to $20.0 \mathrm{mg} / \mathrm{ml}$ aseptically, mixed gently in the test tubes. The test tubes were inoculated with the appropriate bacteria and fungi culture, previously diluted to about $10^{5} \mathrm{cfu} / \mathrm{ml}$. The test tubes were then incubated at $37^{\circ} \mathrm{C}$ for 24 hours for the nutrient broth, while the test tubes containing the Potato dextrose broth for the fungal isolates were incubated at $28^{\circ} \mathrm{C}$ for 72 hours. The lowest concentration preventing visible growth in each determination was taken as the minimum inhibitory concentration.

Determination of Minimum Bactericidal Concentration (MBC): This was an offshoot of the previously determined MIC. The least concentration of the plant extract in the test tube with no turbidity was taken as the minimum inhibitory concentration (MIC). Subsequently, those tubes that showed no turbidity were plated out on nutrient agar plate, and absence of growth on incubation for 24 hours was confirmed as minimum bactericidal concentration (MBC).

Phytochemical analysis: Qualitative tests for alkaloids, tannins, glycosides, saponins, flavonoids, steroids, triterpenes, phytate were according to standard methods such as Mayer's reagent for alkaloids, Fehlings solution for determination of glycosides,
Frothing test and Emulsion test for determination of saponins while Qualitative phytochemical analysis was carried out using standard methods such as the spectrophotometric method for determination of tannins and flavonoids, determination of total alkaloids was done using standard procedures [6] and use of Fehlings solution for determination of total glycosides.

\section{RESULTS}

In general, the ethanol extracts were observed to be more potent and consistent in activity than the aqueous extracts of $K$. senegalensis. The antimicrobial activity of the crude extracts revealed ethanol extract of the seed had higher antibacterial activity compared to aqueous extracts (Table 1 ).

Table 1: Antimicrobial Activity of Crude K. senegalensis Seed Extract.

\begin{tabular}{|l|l|l|}
\hline Test Isolates & $\begin{array}{l}\text { Ethanol } \\
\text { extract (mm) }\end{array}$ & $\begin{array}{l}\text { Aqueous } \\
\text { extract (mm) }\end{array}$ \\
\hline $\begin{array}{l}\text { Pseudomonas } \\
\text { aeruginosa }\end{array}$ & 29.0 & 12.0 \\
\hline $\begin{array}{l}\text { Staphylococcus } \\
\text { aureus }\end{array}$ & 25.0 & 0.0 \\
\hline Bacillus subtilis & 17.0 & 0.0 \\
\hline Escherichia coli & 28.0 & 13.0 \\
\hline Candida albicans & 13.0 & 7.0 \\
\hline Penicillium notatum & 11.0 & 10.0 \\
\hline Aspergillus niger & 11.0 & 6.0 \\
\hline
\end{tabular}

The fungal organisms showed antimicrobial sensitivity when the extracts were used in the crude state (Table 1 ), but when they were used in concentrations of up to 20 $\mathrm{mg} / \mathrm{ml}$; there was no sign of sensitivity in any of the fungi. This infers that very large quantities of the seed samples of $K$. senegalensis are needed for the antimicrobial sensitivity of the fungi. However, at the crude state of the sample (Table 1), Candida albicans was recorded as the most sensitive fungus, with an inhibition diameter of $13.0 \mathrm{~mm}$ (ethanol extract). The extract recorded no activity against any of the organisms at 5 $\mathrm{mg} / \mathrm{ml}$. However, the inhibitory effects were observed, in an ascending order, across the other concentrations of $10 \mathrm{mg} / \mathrm{ml}$, $15 \mathrm{mg} / \mathrm{ml}, 20 \mathrm{mg} / \mathrm{ml}, 30 \mathrm{mg} / \mathrm{ml}$ and $40 \mathrm{mg} / \mathrm{ml}$. Table 2 shows that Pseudomonas aeruginosa had the highest zone of inhibition $(22.00 \mathrm{~mm})$ at $20 \mathrm{mg} / \mathrm{ml}$. The fungi isolates did not record any zone of inhibition at these concentrations.

Table 2: Antimicrobial Zone of Inhibition (mm) Activity of Aqueous and Ethanol Extracts of K. senegalensis Seed.

\begin{tabular}{|c|c|c|c|c|c|c|c|}
\hline \multirow[t]{2}{*}{ Test Isolates } & \multirow[t]{2}{*}{ Extract } & \multicolumn{4}{|c|}{ Concentration (mg/ml) } & \multicolumn{2}{|c|}{ Control } \\
\hline & & 5 & 10 & 15 & 20 & GN & CPX \\
\hline \multirow{2}{*}{$\begin{array}{l}\text { Pseudomonas } \\
\text { aeruginosa }\end{array}$} & Aq. & $0.00 \pm 0.00$ & $0.00 \pm 0.00$ & $0.00 \pm 0.00$ & $2.33 \pm 0.33$ & 14.00 & 15.00 \\
\hline & $\mathrm{OH}$ & $0.00 \pm 0.00$ & $3.33 \pm 0.33$ & $16.00 \pm 0.58$ & $22.00 \pm 0.58$ & 14.00 & 15.00 \\
\hline \multirow{2}{*}{$\begin{array}{l}\text { Staphylococcus } \\
\text { aureus }\end{array}$} & Aq. & $0.00 \pm 0.00$ & $0.00 \pm 0.00$ & $0.00 \pm 0.00$ & $0.00 \pm 0.00$ & 10.00 & 20.00 \\
\hline & $\mathrm{OH}$ & $0.00 \pm 0.00$ & $10.00 \pm 0.58$ & $15.67 \pm 0.33$ & $19.00 \pm 0.58$ & 10.00 & 20.00 \\
\hline \multirow[t]{2}{*}{ Bacillus subtilis } & Aq. & $0.00 \pm 0.00$ & $0.00 \pm 0.00$ & $0.00 \pm 0.00$ & $0.00 \pm 0.00$ & 20.00 & 22.00 \\
\hline & $\mathrm{OH}$ & $0.00 \pm 0.00$ & $0.00 \pm 0.00$ & $10.67 \pm 0.33$ & $14.33 \pm 0.33$ & 20.00 & 22.00 \\
\hline \multirow[t]{2}{*}{ Escherichia coli } & Aq. & $0.00 \pm 0.00$ & $0.00 \pm 0.00$ & $0.00 \pm 0.00$ & $0.00 \pm 0.00$ & 11.00 & 10.00 \\
\hline & $\mathrm{OH}$ & $0.00 \pm 0.00$ & $8.00 \pm 0.58$ & $15.00 \pm .58$ & $19.67 \pm 0.33$ & 11.00 & 10.00 \\
\hline
\end{tabular}




\begin{tabular}{|l|l|l|l|l|l|l|l|}
\hline Candida albicans & Aq. & $0.00 \pm 0.00$ & $0.00 \pm 0.00$ & $0.00 \pm 0.00$ & $0.00 \pm 0.00$ & - & - \\
\cline { 2 - 8 } & OH & $0.00 \pm 0.00$ & $0.00 \pm 0.00$ & $0.00 \pm 0.00$ & $0.00 \pm 0.00$ & - & - \\
\hline \multirow{2}{*}{$\begin{array}{l}\text { Penicillium } \\
\text { notatum }\end{array}$} & Aq. & $0.00 \pm 0.00$ & $0.00 \pm 0.00$ & $0.00 \pm 0.00$ & $0.00 \pm 0.00$ & - & - \\
\cline { 2 - 8 } & OH & $0.00 \pm 0.00$ & $0.00 \pm 0.00$ & $0.00 \pm 0.00$ & $0.00 \pm 0.00$ & - & - \\
\hline Aspergillus niger & Aq. & $0.00 \pm 0.00$ & $0.00 \pm 0.00$ & $0.00 \pm 0.00$ & $0.00 \pm 0.00$ & - & - \\
\cline { 2 - 8 } & OH & $0.00 \pm 0.00$ & $0.00 \pm 0.00$ & $0.00 \pm 0.00$ & $0.00 \pm 0.00$ & - & - \\
\hline
\end{tabular}

$\mathrm{n}=3$; Values are Mean \pm SEM; GN= Gentamycin; $\mathrm{CPX}=$ Ciprofloxacin; Aq. = Aqueous $\mathrm{OH}=$ ethanol; - = Not detected.

The ethanol extract recorded the highest inhibitory effect of $22.00 \mathrm{~mm}$ at $20 \mathrm{mg} / \mathrm{ml}$ (Table 2). These results confirm earlier studies that observed that plant extracts in organic solvents provide more consistent antimicrobial activity, compared to those extracted in water [7-8]. Compared with the positive control (Ciprofloxacin and Gentamycin), it was observed that the samples had a higher antimicrobial activity against $P$. aeruginosa, S. aureus and E. coli than the control (Table 2). Table 3 reveals the minimum inhibitory concentration (MIC) and minimum bactericidal/fungicidal concentrations (MBC/MFC) of the seed extract of $K$. senegalensis. It can be observed generally from the MIC values (Table 3), that the ethanol activity is better than the aqueous activity.

Table 3: Minimum Inhibitory Concentration (MIC) and Minimum Bactericidal/Fungicidal Concentrations (MBC/MFC) of Aqueous and Ethanol Extracts of K.senegalensis Seed.

\begin{tabular}{|l|l|l|l|}
\hline Test Isolates & Extracts & MIC & MBC/MFC \\
\hline \multirow{2}{*}{$\begin{array}{l}\text { Pseudomonas } \\
\text { aeruginosa }\end{array}$} & Aq. & 20.0 & 10.0 \\
\cline { 2 - 4 } & OH & 8.0 & 10.0 \\
\hline \multirow{2}{*}{$\begin{array}{l}\text { Staphylococcus } \\
\text { aureus }\end{array}$} & Aq. & 0.0 & 0.0 \\
\cline { 2 - 4 } Bacillus subtilis & OH & 8.0 & 15.0 \\
\cline { 2 - 4 } & Aq. & 0.0 & 0.0 \\
\hline \multirow{3}{*}{ Escherichia coli } & Aq. & 13.0 & 15.0 \\
\cline { 2 - 4 } & OH & 20.0 & 20.0 \\
\hline Candida albicans & Aq. & 0.0 & 10.0 \\
\cline { 2 - 4 } & OH & 0.0 & 0.0 \\
\hline Penicilliumnotatum & Aq. & 0.0 & 0.0 \\
\cline { 2 - 4 } & OH & 0.0 & 0.0 \\
\hline Aspergillusniger & Aq. & 0.0 & 0.0 \\
\cline { 2 - 4 } & OH & 0.0 & 0.0 \\
\hline
\end{tabular}

Aq. = Aqueous, $\mathrm{OH}=$ ethanol, $\mathrm{MIC}=$ Minimum inhibitory concentration, $\mathrm{MBC} / \mathrm{MFC}=$ Minimum bactericidal/ Minimum fungicidal.

Table 4 reveals the preliminary qualitative phytochemical analysis and the quantitative phytochemical analysis $(\mathrm{mg} / 100)$ of $K$. senegalensis seed while Table 5 reveals the proximate nutritive Values (mg/kg) of K. senegalensis seed.

Table 4: Qualitative and Quantitative analysis of K.senegalensisSeed.

\begin{tabular}{|l|l|l|}
\hline Parameters & $\begin{array}{l}\text { Qualitative } \\
\text { analysis }\end{array}$ & $\begin{array}{l}\text { Quantitative analysis } \\
\text { (mg/100) }\end{array}$ \\
\hline Alkaloids & + & 2.05 \\
\hline
\end{tabular}

\begin{tabular}{|l|l|l|}
\hline Tannins & + & 2.36 \\
\hline Flavonoids & - & - \\
\hline Saponins & + & 3.16 \\
\hline Glycosides & - & - \\
\hline Phytates & + & 6.74 \\
\hline Oxalates & + & 1.88 \\
\hline
\end{tabular}

$+=$ detected, - = not detected.

The results of the phytochemical screening of the seed extract of $K$. senegalensis (Table 4), revealed the presence of alkaloids, tannins, saponins, phytatesand oxalates with phytate being the highest while flavonoids and glycosides were absent. In previous research reports, the presence of Saponins and Tannins and the absence of glycosides and flavonoids were confirmed in K. senegalensis plant [9]. Although,[9] indicated the absence of Alkaloids, the presence of alkaloids in $K$. senegalensis was confirmed. Macro and micro elements like Sodium, Potassium, Calcium, Magnesium, Iron, Zinc, Lead and Manganese were also observed in the seed extract of $K$. senegalensis (Table 5).

Table 5: Proximate Nutritive Values (mg/kg) of K. senegalensis Seed

\begin{tabular}{|l|l|}
\hline Parameters & Values (mg/ml) \\
\hline Sodium & 37.71 \\
\hline Potassium & 40.05 \\
\hline Calcium & 24.14 \\
\hline Magnesium & 27.98 \\
\hline Iron & 12.11 \\
\hline Zinc & 17.67 \\
\hline Lead & 0.85 \\
\hline Manganese & 3.59 \\
\hline Chromium & - \\
\hline
\end{tabular}

\section{CONCLUSION}

The results from this study provide evidence that the aqueous and ethanol extracts of the seed of $K$. senegalensis contains some phytochemicals that are essential in pharmaceutical, food and medicine industries. The presence of secondary metabolites might be responsible for the plant's medicinal properties. There is the need to consider the use of potent extracts from the seed of $K$. senegalensis that have shown some measure of antimicrobial potency, judging from the significant antimicrobial activity, MIC, MBC and phytochemical screening results of the extracts. However, further studies are recommended on the chemical characterization and biological availability of the extract. 


\section{REFERENCES}

1. A. Shajahan, S. Ramesh, Antimicrobial activity of crude ectocarp extract of Punica granatum against some selected enteropathogenic bacteria. Assoc. J. Microbiol. Biotech Environ. Sci 6 (2004) 647- 648.

2. R. Baker, R. Sorrie, S. Reddish, H. Hearnshaw, N. Robertson, The facilitation of multi-professional clinical audit in primary health care- from adult to quality assurance. J. interprof care 9 (1995) 237-244.

3. Anonymous, Forestry Compendium-A Silvicultural Reference Global Module. CAB International, Wallingford, UK, 2000.

4. Anonymous, The Convention on International Trade in Endangered Species of wild fauna and flora (CITES). (http://www.cites.org/index.html) 2004.
5. J.M. Boffa, Agroforestry Parklands in Sub-Saharan Africa FAO, Conservation Guide, No. 34, Rome 1999.

6. J.B. Harborne, Phytochemical methods. Chapman and Hall, Ltd. London,1973.

7. J. Parekh, D. Jadeja, S. Chanda, Efficacy of aqueous and methanol extracts of some medicinal plants for potential antibacterial activity. Turk. J. Biol 29 (2005)203-210.

8. I. Ahmad, Z. Mehamood, F. Mohammad, Screening of some Indian medicinal plants for their antimicrobial properties .J. Ethnopharm 62 (1998)183-193.

9. D. Kubmarawa, M.E. Khan, A.M. Punah, M. Hassan, Phytochemical screening and antimicrobial efficacy of extracts from Khaya senegalensis against human pathogenic bacteria. Afr. J. Biotech, 7 (2008) 4563- 4566.

Citation: M. Idu, et al (2014). Phytochemical Composition and Antimicrobial Properties of the Seeds of Khaya senegalensis (Desc.) A. Juss. J. of Advanced Botany and Zoology, V1I4. DOI: 10.15297/JABZ.V1I4.03.

Copyright: (C) 2014 M. Idu. This is an open-access article distributed under the terms of the Creative Commons Attribution License, which permits unrestricted use, distribution, and reproduction in any medium, provided the original author and source are credited. 